\title{
THE STIMULATION OF PROFESSIONAL SELF-IMPROVEMENT OF PRIMARY SCHOOL TEACHERS IN THE POSTGRADUATE EDUCATION SYSTEM: TARGET-SETTING
}

\section{Sushchenko L. O.}

\section{INTRODUCTION}

The desire of the teacher for professional self-improvement is a sociopedagogical phenomenon, which is connected with the teacher's personal and value orientations for the best fulfilment of his/her pedagogical functions. Therefore, the theoretical basis for constructing the concept of stimulating the professional self-improvement of teachers in the system of postgraduate education is the modern educational paradigms: humanistic, cultural, the concept of continuing vocational education and acmeological, personally-active, competence, systematic approaches.

In this regard, the active self-expression of one's own professionalism of elementary school teachers covers acts of extraction, above all, his or her targeted professional orientation as the most important socially important internal mover of professional selfimprovement, personal, information traits, which involves their comparison and analysis, abstraction and focus on the main, characterization of the substantive essence of a professional position as a bringer of subjective pedagogical experience, its adequacy, etc. A competent, conscious self-examination of the purpose and effectiveness of one's professional activity is the first mandatory phase of professional self-improvement. But this process should be approached comprehensively. Directing self-development and enriching a teacher's creative potential in one or more directions and neglecting others lead to one-sidedness and do not produce the desired result. As an example, that is excessive praise the innovation, idealization, and sometimes 
falsification of its results, could mostly lead to stereotypes, result in true projection, harms the development of true teacher professionalism ${ }^{1}$.

In the process of pedagogical diagnosis, which is being actively pursued in all structures of postgraduate education, much attention is paid to the identification of problems of a didactic nature, rather than to the study of the professional positions of teachers, which mostly reflects the level of their analytical culture in an objective assessment of their professional level.

In our experiment, there were no cases (327 people were interviewed) that the teacher answered that his/her professionalism was always assessed objectively. The main reason for this situation is that it is not professionalism, not even the professional level of the teacher, not his/her attitude to the educational environment that is being examined and diagnosed, but only some aspects of this complex formation. Own socio-professional positions of teachers are out of focus, as well as revealed an understanding of new pedagogical phenomena from a position of professionalism, resulting in the concealment of unresolved problematic issues, understanding them through the prism of the author's individuality.

In this regard, it should be remembered that teachers belong to the socio-professional group of intelligentsia whose value is the continued opportunity to positively influence on the development of children and those who are around them (parents, neighbours, teachers, etc.). In our view, such an influence is one fundamental impact of the teacher today.

Thus, the professionalism of primary school teachers should be considered as a professionally organized positive pedagogical influence of the teacher on solving difficult situations, which provides him/her with a special socio-professional image among children, parents, colleagues and the school community.

\footnotetext{
${ }^{1}$ Протасова Н. Г. Гуманізація післядипломної освіти педагогів. К., 1998. 151 с.
} 


\section{The conceptualization of approaches in stimulating of professional self-improvement of primary school teachers: psychologically-pedagogical discourse}

We are talking about the special professional status of the teacher, about his indirect role between the state and society, in which he/she, on the one hand, forms a positive image of his state, and on the other consciously changes him/her in the process of teaching. Therefore, in order to determine the pedagogical concept of self-development of teacher's professionalism, it is necessary to distinguish the sphere of parity relations, to define priorities and to emphasize the focus. As I. Ziazun points out, this area of pedagogical design can be conditionally called pedagogical accentology, though it is not only about accents, but, in fact, ways of achieving integrity and harmonious interaction ${ }^{2}$.

Though such a conceptual approach to considering the very essence of the teacher's professional development is weakly supported by his practical activity, for which it has its own reasons.

First, the development of professionalism of primary school teachers occurs not only in complex socio-ideological conflicts, but also in the conditions of radical changes in the field of education, change of norms and moral values, considerable diversity of views and approaches to understanding the category of "professionalism".

Secondly, the personal achievements of the teacher are being evaluated recently outside the priority of humanism, kindness, citizenship, professional virtue, which is the basis of the teacher's professionalism.

Thirdly, such a situation makes it difficult to solve topical problems in training of primary school teachers in the conditions of higher education and in teacher training centers, in postgraduate pedagogical education institutions, which requires deepening of scientific research on this problem.

Thus, these obstacles to the development of teachers' professionalism, approaches in overcoming them are conceptual in nature; they affect the overall status and development of teacher professionalism.

\footnotetext{
2 Зязюн I. А. Гуманізм освіти ХХІ століття : філософський і психологічний аспект. Теорія $і$ практика управління соціальними системами : щоквартальний науково-практичний журнал. 2002. № 2. С. 18-25.
} 
There is an objective need for a modern understanding of the professionalism of the teacher as a social phenomenon, which combines personal qualities, successful moral and intellectual and professionally expedient personal self-realization, professional excellence, which will allow to understand the essence of the process of stimulating professional development and self-development of professional competence, correctly identify the indicators and criteria for career growth ${ }^{3}$.

We consider the professionalism of the teacher as a qualitative-valued pedagogical category, which organically combines social activity, humanistic orientation and responsibility, in-depth and modern psychological and pedagogical knowledge, common moral values, pedagogical excellence, continuous work on professional self-improvement.

The proposed definition of professionalism changes the nature and content of his continuous professional self-improvement throughout its life, its purpose, goal orientation, peculiarities of teacher's interaction with people, especially with children, ways and means of successful advisable interaction, supported by society and subjects of pedagogical process.

It should be noted that the professionalism of the teacher is first of all a subsystem of social activity and social culture. Therefore, his/her study is multidimensional, it has axiological and acmeological character. The effectiveness of the teacher's professional self-development depends to a large extent on the prestige of the profession in the society, which mainly creates the basis for its intensive self-formation. But there are also many contradictions here.

It would not be hard to notice that in the field of view of modern education officials there was and is basically one element of teacher professionalism - the ability to impart intellectual knowledge and skills to children; the deep socio-pedagogical aspects and processes of pedagogical activity stay out of sight.

The analysis of variants of paradigmatic approaches, which define the teacher professionalism, shows that they do not exclude each other, but only complement each other, revealing its different sides.

Сущенко Л. О. Концептуальні засади саморозвитку професіоналізму вчителя. Педагогіка $i$ психологія формування творчої особистості: проблеми і пошуки : зб. наук. пр. / редкол.: Т. І. Сущенко (голов. ред.) та ін. Запоріжжя. 2007. Вип. 47. С. 315-320. 
We will attempt to complement the existing conceptual approaches with the perspective of another paradigm, which allows us to take a different approach to understanding the self-development of teacher's professionalism and the assessment of his/her pedagogical activity. It is about using the laws of new professional thinking in the process of forming the professionalism of teachers, connected with its conceptualization.

The need to conceptualize the process of forming a teacher's professionalism is explained by the global objective processes as they occur around the civilized world. These are, first of all, processes of dialogue and rapprochement of cultures and peoples. Progress in education and pedagogy should be directly measured by the quality of life and communication of each individual; the progress of pedagogical professionalism - the quality of life of each child. Therefore, modern education, civilizational pedagogical process should be understood as the convergence of teacher and child to the culture of civilization in different spheres of their life. This convergence should become a significant criterion for teacher professionalism today.

The core of civilization is culture as spiritual production and reproduction, and the deep foundation of culture, in turn, is the moral foundation and humanistic values of society.

So the question is: what kind of teacher professionalism is needed today to make children in the era of social transformation feel comfortable, think and act in all spheres of being under the canons of culture, so that their activity in history in improving the lives of each person and society is enhanced?

Thus, the professionalism of the teacher today has many new shades of manifestation: in constant scientific research, pedagogical skills, selfeducation aimed at personal professional self-development, in creating an educational environment that excites, amazes and develops the personality of the child, promotes the active self-identification of spiritual self-expression. 
The need for changes in teacher training in the system of postgraduate teacher education meets the challenges of the times, increasing demands and quality transformations in society, therefore, and important social and pedagogical issues. The society needs teachers who would accept the changes which are taking place in education, adapt to them, transform a new educational and philosophical paradigm and work meeting modern requirements. The knowledge gained from the higher education institution cannot predict all occasions, otherwise the imminent standardization of the pedagogical process, which really obstructs creative search. That is why the question of stimulating professional selfimprovement of primary school teachers in the system of postgraduate pedagogical education is urgent.

\section{Factors of influence on stimulation of professional self-improvement of primary school teachers in the system of postgraduate pedagogical education}

The stimulating function of the system of postgraduate education of pedagogues is to increase the interest of teachers in new knowledge, the organization of educational process on the basis of problemmethodological and search methods, which contribute to the dissemination of educational needs and diversify their interests, and not only professional ones. The system of postgraduate education is intended to stimulate selfeducation and self-development of teachers, in every possible way to encourage and support the specialist's desire for education, improvement and development.

Premising that the stimulating function of postgraduate education is the basis of our research, we consider it is necessary to highlight a number of factors of pedagogical influence on the stimulation of professional selfimprovement of primary school teachers. Based on the analysis of scientific sources, it is possible to determine the factors influencing the stimulation of professional self-improvement of teachers (Fig. 1). 


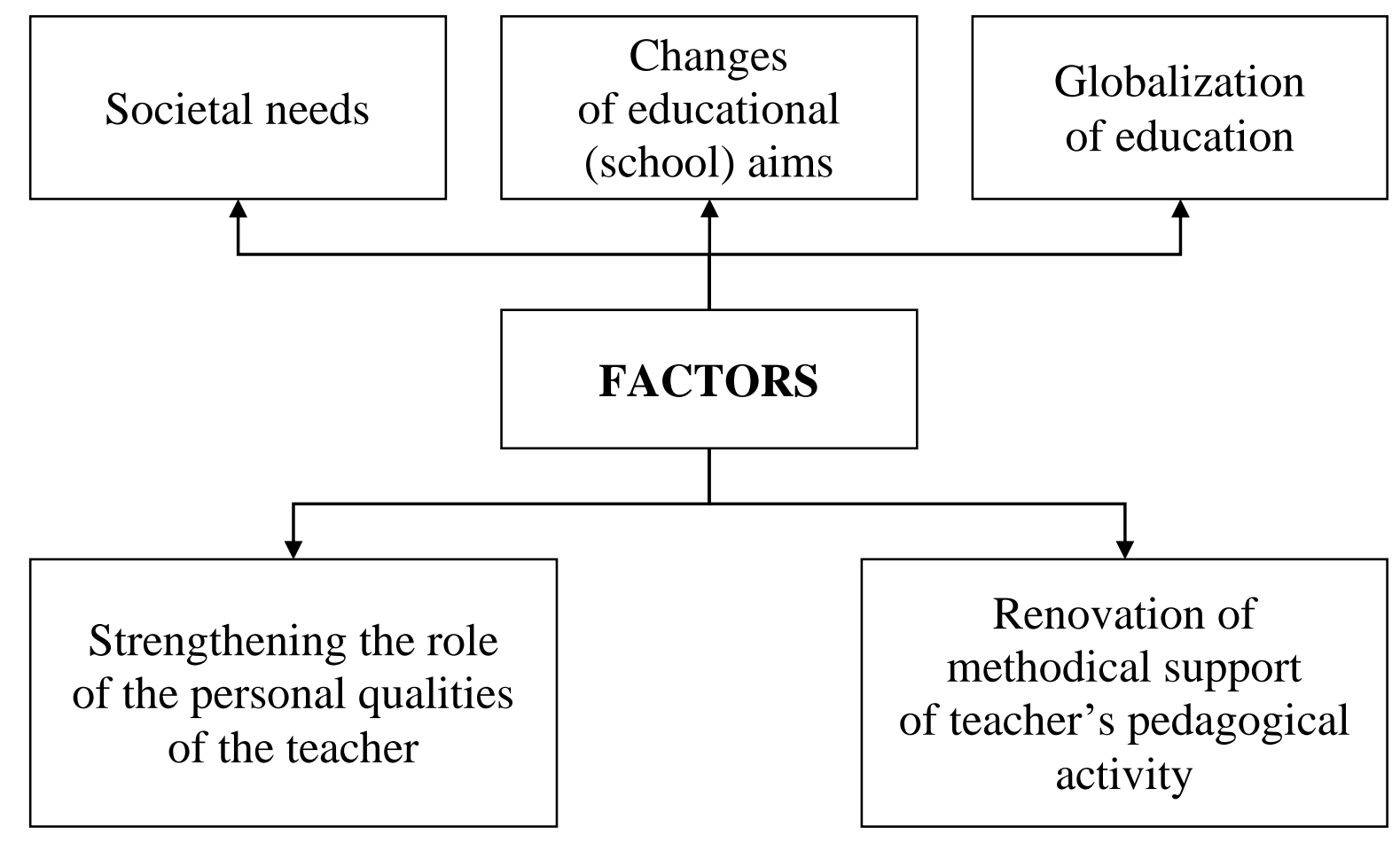

\section{Fig. 1 Factors of influence on stimulation of professional self-improvement of a primary school teacher in the system of postgraduate pedagogical education}

One of the factors can be called the needs of society, i.e. societal and social environment. Today, in times of change, the relevance of knowledge about a man, about the possibilities of its adaptation to the rapidly changing natural, socio-economic and cultural environment, dynamic changes in all spheres of social life is increasing. In today's society, many educators lack such qualities and knowledge as psychological and social readiness to live and work in new conditions, a willingness and ability to deal honourably with unusual and difficult situations, moral stability, and so on.

Becoming an individual is carried out within a context where the natural urge for self-affirmation and success faces ever-increasing competition and increased requirements on the individual in the labour market. Another set of personality traits is needed that enables a person to successfully integrate into a complex social environment: the ability to 
quickly learn a new one, flexibility, dynamics, mobility, the ability to take actions through trial and error.

With the transition to market relations and the democratization of the life of our society, the question of improving the training of teaching staff, the formation of new qualities in them, in particular, the ability to be a leader of the child in his/her self-knowledge, in self-development and especially in self-realization, has been raised. A general educational establishment needs a teacher-psychologist, a teacher-technologist, a teacher-researcher, who must be able to solve creative, high-level complex professional problems. Changes in the nature of teacher-tutor relationships with children are also important. The personality of the teacher is an effective factor in the formation of the pupil's personality. In actual practice, the teacher clearly demonstrates his/her learned behavioural patterns, social norms and values. His/her individual-psychological characteristics determine the values of the pupil. Educational potential of the teacher is not limited to his/her pedagogical technology, because he/she educates pupils, as noted by G. Kostyuk, "his attitude to learning, his organization, relations with pupils, communication with them, his erudition, wealth of spiritual interests, principle, justice, demands on students, as well as attentiveness, observation, understanding of each student's personality, sincerity in dealing with them" ${ }^{4}$.

Educators, by realizing themselves, give meaning the global values of the child. However, only that teacher successfully manages to this mission, who is constantly working on developing own motivation to master the spiritual culture, to deepen and diversify knowledge, focused on the systematic improvement of their professional skills.

Another important factor that not only actualizes professional selfimprovement, but also influences the process of its stimulating, is the globalization of education.

The integration process in science and education has two components: forming a commonwealth of leading European universities under the aegis

\footnotetext{
${ }^{4}$ Костюк Г. Навчально-виховний процес і психічний розвиток особистості. Г. Костюк. К. : Радянська школа, 1989. 608 с.
} 
of the document named the Great Charter of Universities (Magna Charta Universitatum), and the union of national education and science systems into the European space with common requirements, criteria and standards. The main purpose of this process is to consolidate the efforts of the scientific and educational community and governments of Europe to significantly enhance the competitiveness of the European science and higher education system on a global scale, and to enhance the role of this system in social transformation.

Today, it can be stated that, despite the natural achievements of education provided by the new socio-political system (democracy, flexibility, non-ideologization), education has become less qualitative in scale, and the overwhelming majority of graduates of higher education institutions are not competitive in the European labour market. This requires all to talk less about their own achievements and to analyze more the global and European trends in education reform, and according to this to improve own professional field of activity in a diligently and consistent way.

Another important factor is to change the aim (aims) of education, because it is one of the main tasks that the modern school faces.

Today our school is experiencing a difficult but extremely interesting period. New educational models and individual programs sometimes make one think of the "good old days" when the school education was cautiously restricted by stable curricula and provided with clear guidelines.

The appearance of courses for various innovative projects is quite natural: school should and can be as multidimensional and ambiguous as life itself. Alternative programs set new "spaces of opportunity" for children and teachers. However, the opportunity to choose and self-determination remains undesirable for educators, and sometimes it is a kind of annoying factor. The longing for methodological recommendations, a counterweight to some "traditional system of teaching" (which does not mean any particular model, but the very idea of stability, immobility, permanence of learning) makes one think that the flexibility of the teacher, his ability to real professional development is not 
at all depends on state-of-the-art technology (new programs or new equipment), and requires a certain level of formation of very specific abilities that would allow you to change, transform and create your professional style.

The extraordinary flexibility and dynamism of the school education system compels to put the problem of teacher training completely new. In this situation, the attempt to refocus pedagogical education from mastering individual technologies to forming a willingness to choose, learn and use technologies with a new orientation is extremely interesting. Self-determination, professional flexibility, initiative, open-mindedness to the new - all of them are not just individual features of professional activity, but a number of skills that are to be formed. In turn, such traditional characteristics of teachers, such as passivity, motivational weakness, rigidity, reflect non-possessing of specific technologies of transformation of their activity.

Obviously, teacher education should be based on the ideology of development (self-development). The model of teacher training must meet the time requirements and qualitatively change, both substantively and technologically.

O. Vasilyeva believes that professional development is inseparable from the personal: underpinning both is the principle of self-development that determines the ability of the individual to transform their own life in the subject of practical transformation, which is characteristic of the professional development of the teacher. Personal development involves a strategy of releasing inner resources, which include the ability to solve valued-moral problems and, when necessary, confront the environment, actively influence it, and assert its independence from external pressure and the possibility of creative expression. In professional development the teacher is characterized by the ability to see his professional work in its entirety. This provides the teacher with the opportunity to internally accept, understand and evaluate the difficulties and contradictions of the pedagogical process, independently to constructively resolve them in accordance with their value orientations, to consider the difficulties as an 
incentive for further development, as well as overcoming their own boundaries. The teacher's awareness of his potentials, personal and professional growth prospects encourages him to constantly experiment, which is understood as creativity, choice, and search. The leading element in such a situation of teacher's professional development is the ability and need to make choices, to feel his freedom, on the one hand, and his responsibility, on the other ${ }^{5}$.

In our opinion, self-development can only be talked about in cases when the teacher is aware of his involvement and responsibility for everything that happens to him, his pupils (and the school as a whole), and tries to actively promote or counteract external circumstances, plan and set goals of professional activity, to change oneself for achievements. This model is the most productive for the creative realization of the teacher's personality. Creative work, when the actions of the teacher are not composed on a pattern, requires for the successful implementation of a strong, mature, flexible personality, and most importantly, the ability to think independently goals and objectives that most often do not coincide with the common in this school (education system), to strive to achieve. Therefore, everything that contributes to personal and professional self-improvement extends the capacity for creativity.

Another factor of pedagogical influence on stimulation of professional self-improvement of the teacher we consider strengthening of a role of personal qualities of the teacher. The provision is not in the "methodical tricks", but in the process aimed at "awakening" the desire for development and creating the conditions for active professional self-realization.

The analysis of primary sources, historical and pedagogical literature, and researches of scientists concerning the question of personal and professional qualities of the teacher allows to state that the teacher should possess such qualities as responsibility, respect for the personality of the child, colleagues, parents, kindness, tolerance, truthfulness, empathy,

\footnotetext{
5 Васильєва О. А. Професійна діяльність вчителя і основи самореалізації. Педагогіка $і$ психологія формування творчої особистості : проблеми і пошуки : зб. наук. пр. Київ ; Запоріжжя, 2006. Вип. 37. C. 83-90.
} 
gumption, endurance, self-control, principle, decisiveness, justice, efficiency, organizational skills, self-criticism, self-esteem.

M. Borytko identifies three key qualities that are factors of becoming a teacher: reflection, professional consciousness and professional selfesteem. The latter has two manifestations - self-esteem of the result and self-esteem of the potential and the factor of professional development is the combination of low self-esteem of the result with high self-esteem of one's own potential ${ }^{6}$.

Along with the mentioned personal and professional qualities, which have been determined by the teacher for many centuries, the urgent problem of our dissertation is the study of the qualities necessary for one's own professional self-development. In the context of this provision, two models of pedagogical work are distinguished:

1. A model of adaptive behaviour based on adaptation processes. The teacher working on this model is trying to conserve one's energy developed algorithms for performing professional tasks, turning the pedagogical activity itself into a template and stereotyped one.

2. A model of professional development based on the teacher's awareness of his/her own opportunities and perspectives for professional and personal development ${ }^{7}$.

A contemporary understanding of professional self-development is based on the thesis of the need for awareness of the individual as a subject of initiation of his own activity. In this context, the function of the leading characteristics of the personality is fulfilled by such personal and professional qualities as initiative, creativity, responsibility, self-actualization, self-esteem, self-control, self-observation, self-monitoring, self-determination, self-reflection (self-awareness, self-projecting) and so on.

Let us consider the basic concepts. The first part of the compound words "self-" means: first, the focus of action on oneself; secondly, performing the action without assistance.

\footnotetext{
6 Борытко Н. М. Педагог в пространствах современного воспитания. Науч. ред. Н. К. Сергеев. Волгоград : Перемена, 2001. 214 с.

Митина Л. М. Личностное и профессиональное развитие человека в новых социальноэкономических условиях. Вопросы психологии. 1997. № 4. С. 28-39.
} 
Self-esteem is an assessment of oneself, one's abilities, qualities and place among other people. Self-esteem is an important regulator of behaviour. Self-esteem depends on the relationship of the person with others, its criticality, requirements to itself, attitude to successes and failures. Thus, self-esteem affects the effectiveness of activities and the further development of the individual. Self-esteem requires that the individual examine its behaviour or thinking and determine if they are changing.

Self-monitoring is a procedure by which a teacher monitors his or her pedagogical activity and behaviour. Self-monitoring involves self-analysis of activities, current self-correction, allows determining the level of achievement of a goal at a particular stage of activity and is an admission to the following actions.

The ability to reflect, that is, to exercise self-observation, self-analysis, self-esteem, self-control, self-monitoring, self-motivation, defines a teacher as an employee who carries out his pedagogical activity on the basis of his understanding. Such an educator draws lessons from his experience and projects the impact of his own achievements on future professional activity. His/her reflections help to find out if the goal of the activity has been achieved; to identify positive and negative changes in the educational process; to determine whether the methods used in the educational process were not only influential but also justified; whether the predictions of the activities he/she did were precise. Promoting these reflective steps is a difficult task - it takes time to think. Nevertheless, this understanding should occur and be fruitful for the teacher himself and for the education process as a whole. At the same time, favourable conditions are created for the adaptation of the professional interests and needs of the individual teacher to the purpose of the educational institution, to the requirements of management, which is a real force that should be taken into account. As a result, the teacher focuses on the tasks of professional activity within the boundaries based on a dialogue by the unique "I" of his personality. 
Building a professionally-pedagogical activity based on reflective processes has some advantages, namely:

- gives the teacher the opportunity to manage their own behaviour, relationships with other participants in the educational process, pedagogical activities;

- helps to develop responsibility for the consequences of their actions, fulfilment of responsibilities;

- provides personality changes at the behavioural and positional levels;

- develops the ability to make alternative decisions regarding specific pedagogical situations, to choose between rational and irrational, to listen to their own conscience;

- expands opportunities for the realization of a unique "I" of the teacher in practical experience, its development and asserting in the teaching staff and educational space.

The basis of professional self-development is personal selfdevelopment, aimed at developing the creative personality of the teacher. It should be noted that self-development is a person's desire to discover, realize and improve his or her personal qualities. We consider this process as the formation and integration in the pedagogical activity of personal, professional qualities and abilities, methodological, methodical, research knowledge and skills, but the important thing is the active qualitative transformation of the teacher of his inner world, which leads, in fact, to self-actualization and realization of his creative potential. This process is ensured by a certain technology.

The main purpose of the technology of professional self-improvement of the teacher developed by us is realization of a complex of means and conditions that provide formation of the position of teacher-researcher, the increase of cognitive level of personality, its value attitude to innovative and research activity, the realization of creative potential in the process of professional self-development, the formation of the system of analytic and reflexive skills, self-esteem, introspection, reflection and self-reflection of one's own professional level. Summarizing the above, we formulate at 
least as the important factor of pedagogical influence on the professional self-improvement of the teacher - updating of methodological support of pedagogical activity of primary school teachers depending on the stages of their professional formation and development.

Using these theoretical foundations, we consider it would be appropriate to highlight the five hypothetical stages of becoming a professionally-personal self-improvement of educators: adaptation (teacher-specialist, practitioner) $\rightarrow$ differentiation (teacherexperimenter) $\rightarrow$ individualization (teacher-innovator) $\rightarrow$ sustainable self-development (teacher-innovator) $\rightarrow$ self-actualization (teacherresearcher). Each stage is characterized by a special set of factors and conditions that stimulate the teacher's professional and personal development.

We believe that the stage of adaptation is characterized by the need for stimulation and facilitation by institutions of postgraduate pedagogical education and school. The pedagogical goals at this stage are global or blurred, the formation of professional self-awareness, the formation of selfesteem, the processes of self-organization, self-government, self-correction of former stereotypes and ideas are actualized; the interest in the subjects of the pedagogical cycle is actualized, pedagogical activity has a "cumulative" character; as a rule, traditional forms, techniques, methods and tools of teaching are used; there is a formation of practical reflection, the teacher is "inside" the activity, absorbed by the process of its implementation and "sees" it in a fragmented manner. Interaction with colleagues, students, parents, administration, methodologists, non-standard situations in lessons, performing pedagogical tasks when it is used different role positions, motivation for professional success, high level of cognitive activity, awareness of the need to "be meaningful", striving for self-improvement, this is a condition of transition of a teacher-specialist to the differentiation stage.

The differentiation stage is characterized by manifestations of individual uniqueness and is expressed by the degree of development of such qualities as creativity, criticality, formation of methodological 
reflection, strengthening of research orientation; desire to analyze pedagogical problems, facts and phenomena, study of methodology and methods of pedagogical researches. At this stage the technique of teaching the subject is improved; activity is planned and carried out on the basis of knowledge of pedagogical theory and didactic patterns; basic researches are carried out on the basis of plans of research experimental work; the need for personal and professional self-actualization is actualized, the teacher absorbs the position of the experimenter. Increasing cognitive activity, the need for professional and personal self-expression, the formation of creative self-awareness, goal setting, peer review and analysis of colleagues' lessons and own lessons are factors that contribute to the transition of the teacher to the individualization stage.

The individualization stage in the professionally-personal self-development of the teacher is characterized by the formed creative self-awareness, adequate self-esteem, stable skills of self-organization and self-government; the teacher absorbs the position of the innovator - the initiator and implementer of own ideas and pedagogical developments; there is a need for critical analysis and generalization of pedagogical facts, phenomena and processes, mainstreaming of activity for monographic study of one's innovative experience, creation of an "innovative school", development of author's programmes and teaching methodological complexes; technological reflection is developing. The teacher-innovator differs in the qualities of the master and at the same time brings in the work new forms, methods, tools that increase the efficiency of the pedagogical process. Variety of performed pedagogical tasks, interaction with consultants (academics of postgraduate education institutions, universities, methodologists), professional success, opening and realization of creative potential - these are the conditions that contribute to the transition to the stage of sustainable self-development.

The stage of sustainable self-development is characterized by the desire for scientific substantiation of own professional activity, the need to master philosophical, methodological, technological knowledge; the 
teacher moves into the position of an innovator, a complex, systematic activity of whom is aimed at the search, creating and implementing educational innovations that change or update the technology of pedagogical activity and provide personal self-development: ways of organization of educational materials, means of preparation and educational activity of the teacher, elements of educational content, educational content plans and programmes, forms of education, etc. There are organization and improvement of innovative activity, approbation of innovations, scientific-methodical reflection, discussion and review of various pedagogical projects, educationally-methodical complexes, participation in scientific-practical pedagogical conferences, seminars and colloquiums. Forming a "bank" of innovative pedagogical information, unleashing and realizing creative potential are the conditions that contribute to the formation of a teacher-researcher and ensure the transition to the self-actualization stage.

The self-actualization stage is characterized by pedagogical creativity and ability to construct (design and authorship) in creating a conceptual image (model) of pedagogical activity; includes the most complete personal and professional self-realization, development of methodological reflection, awareness and acceptance of humanistic values, creation of own school of the teacher-researcher ${ }^{8}$.

\section{CONCLUSIONS}

Thus, the stimulation of professional self-improvement in our concept transcends the classical aspects of the teacher retraining and is combined with research, scientific and methodological work, and the universalization of professional functions. A special feature of the concept is its focus on stimulating the continuous professional self-improvement in organic unity, continuity and consistency of influence on this process of interaction of the system of postgraduate pedagogical education and school.

\footnotetext{
8 Демічева І. О. Технологія формування дослідницької культури вчителя. Педагогіка $і$ психологія формування творчої особистості : проблеми і пошуки : зб. наук. пр. / редкол. : Т. І. Сущенко (голов. ред.) та ін. Запоріжжя, 2004. Вип. 32. С. 106-112.
} 
In general, the ideas discussed above allow us to draw the following conclusions:

- professional self-improvement of the teacher is considered by researchers in the context of mutual influence of his individual characteristics and socio-cultural environment in the process of socialization and professionalization;

- we suppose the tasks of institutes of postgraduate pedagogical education should not be to directly influence the personality of a self-developing teacher in order to achieve the desired results in the formation of a positive motivation for continuous professional selfimprovement, but in creating the necessary psychological and pedagogical conditions for one's self-building, in stimulating the mechanisms of one's professional self-knowledge, self-acceptance and self-prediction;

- realization of stimulating function of postgraduate pedagogical education - taking into account individual abilities, capabilities and potentials of a specialist; his/her professional experience; needs of mass pedagogical practice; a comprehensive approach to the organization and implementation of continuous professional training of pedagogical staff;

- building and designing a dynamic strategy of personal and professional self-development and self-improvement of teachers aimed at a qualitatively new high level of performing professional tasks on a moral and ethical basis; the sustainable development of professionally-important and personal competencies; the orientation for a high professional achievement with a pronounced desire for a creative search, after all, to be the creator of own professional status, image and prestige.

\section{SUMMARY}

The conceptual bases of the process of stimulating professional selfimprovement of elementary education teachers in the system of postgraduate pedagogical education are presented. It has been found out that modern postgraduate education, which mission is to train highly qualified, competitive, mobile-informed specialists, plays a determining role in solving the problem of lifelong learning. 
The attention is drawn to the fact that the professionalism of primary school teachers should be considered as a qualitative-valued pedagogical category, which organically combines social activity, humanistic orientation and responsibility, deep and modern psychological and pedagogical knowledge, universal human moral values, pedagogical skills, uninterrupted work on professional self-improvement. The proposed definition of professionalism changes the nature and content of one's continuous professional self-improvement throughout one's life, one's purpose, the goal orientation, peculiarities of teacher's interaction with people, especially with children, ways and means of successful, supported by society and subjects of pedagogical process and an appropriate interaction.

It is noted that the society needs teachers who would accept the changes taking place in education, adapt to them, transform them into a new educational and ideological paradigm and work at the level of time requirements.

Based on the outlined conceptual positions, the factors of influence on the stimulation of professional self-improvement of primary school teachers in the system of postgraduate pedagogical education are determined, in particular: the needs of the society, changing the goals of education and its globalization, enhancing the role of the teacher's personal qualities, updating methodological support for teacher's pedagogical activity.

It is found out that in order to understand the relevance and scientifictheoretical statement of the problem of lifelong learning, the necessary preconditions and methodological guidelines are necessary, namely: the idea of subjectivity; the idea of the uniqueness and originality of the inner world of human; the idea of self-actualization of the individual as the highest form of self-development. On the basis of theoretical analysis it is established: a dynamic strategy of personal and professional self-development and selfimprovement of teachers should be aimed at a qualitatively new high level of performing professional tasks on a moral and ethical basis; the sustainable development of professionally-important and personal competencies; the orientation for high professional achievements. 


\section{REFERENCES}

1. Протасова Н. Г. Гуманізація післядипломної освіти педагогів. K., 1998. $151 \mathrm{c}$.

2. Зязюн I. А. Гуманізм освіти XXI століття : філософський i психологічний аспект. Теорія $i$ практика управління сочіальними системами: щоквартальний науково-практичний журнал. 2002. № 2. C. $18-25$.

3. Сущенко Л. О. Концептуальні засади саморозвитку професіоналізму вчителя. Педагогіка $i$ психологія формування творчої особистості: проблеми і пошуки : зб. наук. пр. / редкол.: Т. І. Сущенко (голов. ред.) та ін. Запоріжжя. 2007. Вип. 47. С. 315-320.

4. Костюк Г. Навчально-виховний процес і психічний розвиток особистості. Г. Костюк. К. : Радянська школа, 1989. 608 с.

5. Васильєва О. А. Професійна діяльність вчителя і основи самореалізації. Педагогіка $i$ психологія формування творчої особистості : проблеми $i$ пошуки : зб. наук. пр. Київ : Запоріжжя, 2006. Вип. 37. С. 83-90.

6. Борытко Н. М. Педагог в пространствах современного воспитания. Науч. ред. Н. К. Сергеев. Волгоград : Перемена, 2001. 214 с.

7. Митина Л. М. Личностное и профессиональное развитие человека в новых социально-экономических условиях. Bonpocbl психологии. 1997. № 4. С. 28-39.

8. Демічева I. О. Технологія формування дослідницької культури вчителя. Педагогіка і психологія формування творчої особистості : проблеми і пошуки : зб. наук. пр. / редкол. : Т. І. Сущенко (голов. ред.) та ін. Запоріжжя, 2004. Вип. 32. С. 106-112.

\section{Information about the author: Sushchenko L. O.}

Doctor of Pedagogic Sciences, Associate Professor, Professor at the Department of Education and Management, Classic Private University 70-b, Zhukovskoho str., Zaporizhzhia, 69002, Ukraine 